\title{
EDUKASI KESEHATAN PENCEGAHAN RISIKO DIABETES MELITUS DI DESA SIJAU KECAMATAN RIMBO TENGAH BUNGO
}

\section{Zahlimar $^{1 *}$, Zuriati Zuriati ${ }^{2}$, Melti Suriya ${ }^{3}$}

\author{
Keywords : \\ Diabetes Melitus, \\ Edukasi Kesehatan.

\section{*Corespondensi Author} \\ ${ }^{1}$ Manajemen, Akper Setih Setio Bungo \\ ${ }^{2}$ Zuriati, Universitas Binawan Jakarta \\ ${ }^{3}$ Melti Suriya, STIKes Alifah Padang \\ Email: zahlimar@yahoo.co.id
}

\begin{abstract}
Abstrak. World Health Organization (WHO) memprediksikan penyakit diabetes mellitus (DM) akan menimpa lebih dari 21 juta penduduk Indonesia di tahun 2030. Untuk menekan angka tersebut maka salah satu upaya pemerintah dalam mengendalikan penyakit diabetes mellitus dengan langkah preventif dan pengendalian risiko diabetes mellitus melalui cara melakukan promosi kesehatan. Promosi kesehatan dengan memberikan edukasi tentang penyakit diabetes mellitus beserta komplikasi lebih lanjut dan juga cara pencegahannya dan pengendalian diabetes mellitus. Tujuan kegiatan pengabdian masyarakat ini adalah untuk memberikan informasi kesehatan tentang diabetes mellitus kepada masyarakat desa Sijau Rimbo tengah Bungo. Ada beberapa metode yang dilakukan selama memberikan edukasi yaitu dengan ceramah, diskusi tanya jawab. Dari hasil edukasi yang diberikan didapatkan bahwa tingkat pengetahuan baik sebelum diberikan edukasi kesehatan sebesar 15,3\%, sedangkan setelah diberikan edukasi sebesar 70,6\%. Diharapkan petugas kesehatan dapat melakukan pengontrolan kepada masyarakat dan masyarakat dapat selalu rutin memanfaatkan posbindu yang sudah ada di dalam Kecamatan Rimbo Tengah Kabupaten Bungo.
\end{abstract}

\section{Pendahuluan}

Seiring berkembangnya zaman, teknologi, dan kehidupan sosial, berdampak pada berbagai aspek di antaranya adalah kesehatan. Saat ini Indonesia sedang menghadapi double burden disease yaitu penyakit menular (penyakit infeksi) dan penyakit tidak menular (penyakit degeneratif) yang semakin meningkat. Pada masa sekarang, penyakit tidak menular telah menggeser penyakit infeksi sebagai penyakit yang mendominasi dan menjadi penyebab kematian tertinggi. Diabetes Mellitus menjadi penyebab terbesar kerugian kesehatan di Indonesia, (IHME,2018). Penyakit jantung dan pembuluh darah juga merupakan penyakit penyebab kematian tertinggi di Indonesia (Kemenkes, 2017).
International Diabetes federation (IDF) menjelaskan bahwa Diabetes Melitus merupakan salah satu penyakit kronis paling umum di dunia, terjadi ketika produksi insulin pada pankreas tidak mencukupi atau pada saat insulin tidak dapat digunakan secara efektif oleh tubuh (IDF, 2017)

Berdasarkan hasil penelitian (Hidayah, 2019) tentang Hubungan Perilaku SelfManagement Dengan Kadar Gula Darah Pada Pasien Diabetes Mellitus Tipe 2 Di Wilayah Kerja Puskesmas Pucang Sewu, Surabaya didapatkan bahwa sebagian responden memiliki tingkat self-management baik $(59.5 \%)$ dari pengaturan pola makan, dan kepatuhan konsumsi obat, sebagian besar responden termasuk dalam kategori baik, namun pada aspek aktivitas fisik/olahraga, perawatan diri/kaki, dan 


\section{Zahlimar, dkk. Edukasi Kesehatan Pencegahan Risiko Diabetes Melitus di Desa Sijau Kecamatan Rimbo Tengah Bungo}

monitoring gula darah masih dalam kategori kurang. Selain itu, sebagian besar responden memiliki kadar gula darah yang terkontrol $(50,6 \%)$.

Selain itu berdasarkan hasil penelitian (Zuriati, 2018) menunjukkan bahwa aktivitas fisik merupakan factor yang mempengaruhi peningkatan gula darah, berdasarkan hasil penelitian terdapat perbedaan antara kadar gula darah sebelum dan setelah dilakukan senam pada pasien diabetes melitus di Puskesmas Pauh Padang.

Tujuan penatalaksanaan DM adalah mengurangi risiko komplikasi penyakit mikrovaskuler dan makrovaskuler dan meningkatkan kualitas hidup penderita DM. Pengelolaan yang salah, upaya pencegahan komplikasi DM yang kurang tepat dapat berpotensi mempengaruhi kualitas hidup pasien DM dan salah satu upaya yang dapat dilakukan untuk meningkatkan kualitas hidupnya adalah dengan mengikutsertakan pasien dalam perawatan dirinya sehari hari.

Menurut (Woodall et al., 2013), strategi pemberdayaan dibutuhkan dalam meningkatkan kualitas perawatan dirinya dan strategi tersebut tidak akan bermakna bila pasien DM tidak memiliki kemauan untuk berubah dan bertanggung jawab terhadap dirinya. Kemampuan individu untuk mengontrol diri dan menentukan pilihannya dilakukan dalam rangka meningkatkan kesadaran diri, mengembangkan perilaku yang positif dan meningkatkan kemampuan diri dalam merawat dirinya sendiri sepanjang hayatnya.

Upaya yang dilakukan pemerintah Indonesia dalam mengatasi permasalahan terkait diabetes militus yaitu dengan dikeluarkannya program pengendalian diabetes mellitus pada tahun 2008, pelaksanaan program pengendalian diabetes mellitus ditekankan pada promotif dan preventif tanpa mengabaikan kuratif dan rehabilitatif. Untuk meningkatkan cakupan skrining diabetes mellitus, pelayanan skrining masuk kedalam salah satu program standar pelayanan minimal (SPM) bidang kesehatan yaitu indikator pelayanan kesehatan pada usia 1559 tahun.

Peningkatan pengetahuan pasien diperlukan untuk memandirikan pasien dan Miley (1999) mengungkapkan bahwa kepercayaan akan kesehatan, peningkatan pengetahuan dan perbaikan perilaku akan mempengaruhi pasien DM dalam mengontrol penyakitnya. Merujuk pada sejumlah penelitian, perawatan mandiri yang komprehensif, baik secara langsung maupun tidak langsung, dapat menurunkan angka kesakitan, kecacatan dan kematian yang disebabkan oleh penyakit tersebut Beberapa literatur juga menyimpulkan bahwa pengendalian DM akan lebih efektif bila diprioritaskan pada pencegahan dini melalui upaya perawatan mandiri di rumah (home health care) dengan upaya promotif dan preventif tanpa mengabaikan upaya kuratif dan rehabilitatif dan dengan memberdayakan pasien dalam perawatan dirinya dipercaya efektif untuk merubah perilaku dalam mengontrol penyakitnya termasuk kepatuhan dalam monitoring tanda tanda klinisnya (Ernawati dkk, 2015; Nuari, 2016; Triyanto dkk, 2015).

Olehnya itu, kegiatan pengabdian kepada masyarakat (PKM) di Desa Sijau, Kecamatan Rimbo Tengah Kabupaten Bungo dengan tujuan memberikan penyuluhan berupa edukasi kesehatan tentang pencegahan resiko Diabetes Melitus di masyarakat. Pentingnya kegiatan ini dikarenakan masyarakat di desa sijau termasuk angka berisiko penyakit DM, dilihat dari pola hidup masyarakat dari pola makan dan kebiasaan kurang olah raga juga melakukan pengontrolan rutin ke posbindu. Dari hasil survey awal didapatkan kurang nya pemahaman masyarakat tentang risiko penyakit DM dan bagaimana pencegahannya agar tidak terjadi DM dan komplikasi lebih lanjut.

\section{Metode}

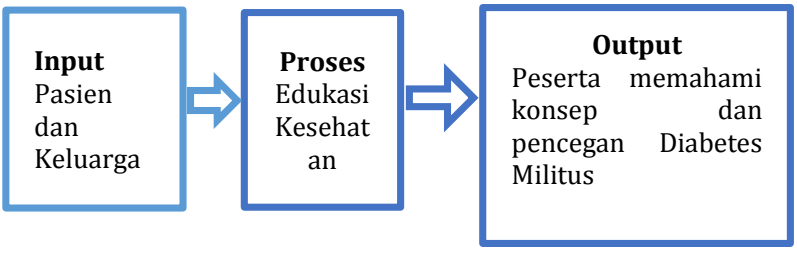

Gambar 1. Proses Pemberian Edukasi Kesehatan Diabetes Militus

Metode penelitian menjelaskan tentang: Pelaksanaan kegiatan Pengabdian kepada Masyarakat berupa pemberian informasi kepada masyarakat tentang pencegahan penyakit Diabetes Meliitus dengan memberikan informasi penyakit DM, pola makan , aktivitas fisik dan pemeriksaan gula darah. Kegiatan pengabmas dilakukan dengan metode ceramah, diskusi. Peserta pengabmas ini yaitu warga di Desa Sijau, 


\section{Zahlimar, dkk. Edukasi Kesehatan Pencegahan Risiko Diabetes Melitus di Desa Sijau Kecamatan Rimbo Tengah Bungo}

sebanyak 20 orang. Kegiatan ini dilaksanakan pada tanggal 15 Januari 2021 di di Desa Sijau, Kecamatan Rimbo Tengah Kabupaten Bungo

Adapun uraian kegiatan pelatihan pengabdian kepada masyarakat yaitu sebagai berikut:
a. Memberikan pretest tentang Diabetes Melitus
b. Memberikan Penyuluhan dengan metode ceramah dengan memberikan penjelasan materi tentang konsep DM
c. Metode diskusi dengan sesi tanya jawab
d. Pemeriksaan kesehatan Kadar Gula Darah

\section{Hasil dan Pembahasan}

Berdasarkan hasil didapatkan bahwa tingkat pengetahuan baik sebelum diberikan edukasi kesehatan sebesar 15,3\%, sedangkan setelah diberikan edukasi sebesar 70,6\%. Dari hasil yang didapatkan terlihat masyarakat desa Sijau Rimbo Tengah Bungo dapat memahami informasi yang diberikan dan diharapakn dapat di aplikasikan dalam kehidupan sehari-harinya.

Diabetes melitus adalah penyakit metabolik yang berlangsung lama (kronis) serta ditandai dengan kadar gula (glukosa) darah yang tinggi atau di atas nilai normal. Salah satu dampak peningkatan kadar glukosa darah yang tidak terkontrol adalah nefropati diabetik (komplikasi DM). Nefropati diabetik adalah komplikasi mikrovaskular DM yang progresif dan mengancam kehidupan sehingga memerlukan dukungan berkesinambungan dan penanganan yang komprehensif.

Terkait penelitian (Suriya, 2016) didapatkan hasil terdapat factor Diet, keselamatan rasa aman, dukungan keluarga dengan kualitas hidup pasien Diabetes Mellitus. Sehingga dengan kurangnya pengetahuan dan lama penyakit mengakibatkan kualitas hidup pasien menurun

Menurut Nfor dan Nyamu (2014), dukungan keperawatan yang harus disediakan untuk kelompok pasien dan keluarga mereka, salah satunya adalah dengan memberikan pendidikan kesehatan yang komprehensif untuk pasien dan keluarga untuk meningkatkan kesadaran diri (selfawareness), dukungan keluarga dalam mengembangkan keterampilan manajemen diri, dukungan psikososial dan pemantauan/monitoring yang berkelanjutan.
Sehingga Diabetes Mellitus dapat diminimalkan dan dicegah dengan pemberian penyuluhan kesehatan karena itu akan sangat efektifuntuk mencegah terjadinya komplikasi. Ketika seseorang akan mengadopsi suatu prilaku maka terlebih dahulu dia harus tahu apa arti dan manfaat prilaku tersebut bagi dirinya, maka akan terbentuklah suatu perubahan prilaku dari yang tidak baik menjadi baik. Pemberian pendidikan kesehatan yang baik dan tepat dapat meningkatkan kesadaran penderita DM untuk mau mengubah perilaku dalam menjalani program pengobatan yang diberikan sehingga kadar gula darah dapat dikendalikan dan mencegah komplikasi.

Merujuk pada hasil penelitian, sebagian responden pada tahap awal pengkajian, belum mampu melakukan perawatan diri dengan baik yang ditandai oleh peningkatan nilai kadar gula darah sewaktu dan puasa berdasarkan hasil pemeriksaan laboratorium, dan kemungkinan salah satu faktor yang berkontribusi adalah kurangnya pengetahuan responden terutama pada aspek perawatan diri sehari hari. Aspek pengetahuan menjadi penting bila dihubungkan dengan perawatan pada penyakit kronis, hal ini dikarenakan pengetahuan menjadi dasar bersikap dan berprilaku dalam perawatan dirinya sepanjang hayat. Diharapkan pengetahuan yang baik membantu pasien DM untuk mengembangkan pola hidup yang sehat, sesuai kebutuhan sehingga pasien dapat hidup berdampingan dengan penyakitnya dan pada akhirnya komplikasi nefropati diabetik tidak terjadi.

Terkait hasil penelitian Rikanurrizki dkk (2017), menunjukkan bahwa kesadaran tentang manajemen dan pencegahan diabetes mellitus meningkat setelah diberikan penyuluhan kesehatan melalui SMS dengan adanya perbedaan nilai mean antara kelompok kontrol dan intervensi sebesar 1,46 dengan p-value 0,007 atau $\mathrm{p} \leq 0,05$. Merujuk pada hasil penelitian Cheng dan Man (2006), disimpulkan bahwa peningkatan kesadaran diri memberikan dampak positif pada pasien.

Hasil penelitian tersebut sesuai dengan teori bahwa salah satu penatalaksanaan DM adalah pendidikan kesehatan terutama tentang komplikasi DM. Pendidikan kesehatan ini sangatlah bagus untuk meningkatkan pengetahuan pasien diabetes mellitus. Pendidikan kesehatan merupakan suatu bentuk 


\section{Zahlimar, dkk. Edukasi Kesehatan Pencegahan Risiko Diabetes Melitus di Desa Sijau Kecamatan}

Rimbo Tengah Bungo

tindakan mandiri keperawatan untuk membantu klien baik individu, kelompok, maupun masyarakat dalam mengatasi masalah kesehatannya melalui kegiatan pembelajaran, yang didalamnya perawat berperan sebagai perawat pendidik. Adapun tujuan yang diperoleh setelah dilakukan penyuluhan kesehatan untuk meningkatkan status kesehatan, mencegah timbul komplikasi salah satunya hipoglikemia, mempertahankan derajat kesehatan yang sudah ada, memaksimalkan fungsi dan peran pasien selama sakit, serta membantu pasien dan keluarga untuk mengatasi masalah kesehatan khususnya tentang hipoglikemia, baik penanganan atau pencegahan.

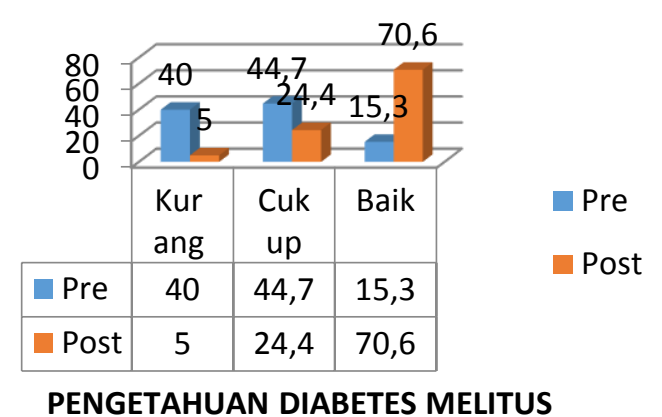

Grafik 1. Hasil Tingkat Pengetahuan Pre dan Post Edukasi Kesehatan

$\begin{array}{ccc}\text { Program } & \begin{array}{c}\text { dukungan } \\ \text { kendidikan }\end{array} & \text { pengembangan } \\ \text { kenatan } & \text { (Supportive }\end{array}$

Developmental Nursing Education Program) sebagai bagian dari model yang dikembangkan memberikan pengaruh yang besar dalam pengelolaan dan pencegahan penyakit kronis, hal ini dikarenakan pemberian pemahaman yang benar tentang penyakit dan penanganannya dan sesuai kebutuhan pasien menjadi dasar dalam perawatan dirinya sehari hari. Secara singkat, pendidikan kesehatan menjadi salah satu bagian penting dalam perawatan diri, Disler et al. (2015) menyampaikan bahwa perolehan pengetahuan adalah salah satu faktor yang diperlukan dalam memberdayakan pasien untuk mengenali kekuatan mereka sendiri dan untuk mengelola dampak dari kondisi sakit tersebut. Pengetahuan adalah hasil dari memperoleh informasi yang didapat melalui penginderaan terhadap suatu objek. Penyelenggaraan pendidikan kesehatan dapat meningkatkan pengetahuan penderita DM. Pengetahuan merupakan dasar utama berhasilnya suatu pengobatan. Pendidikan kesehatan yang efektif didukung oleh penggunaan media yang menarik dan lebih mudah diterima oleh sasaran. Salah satu media yang dapat digunakan adalah media audio visual.
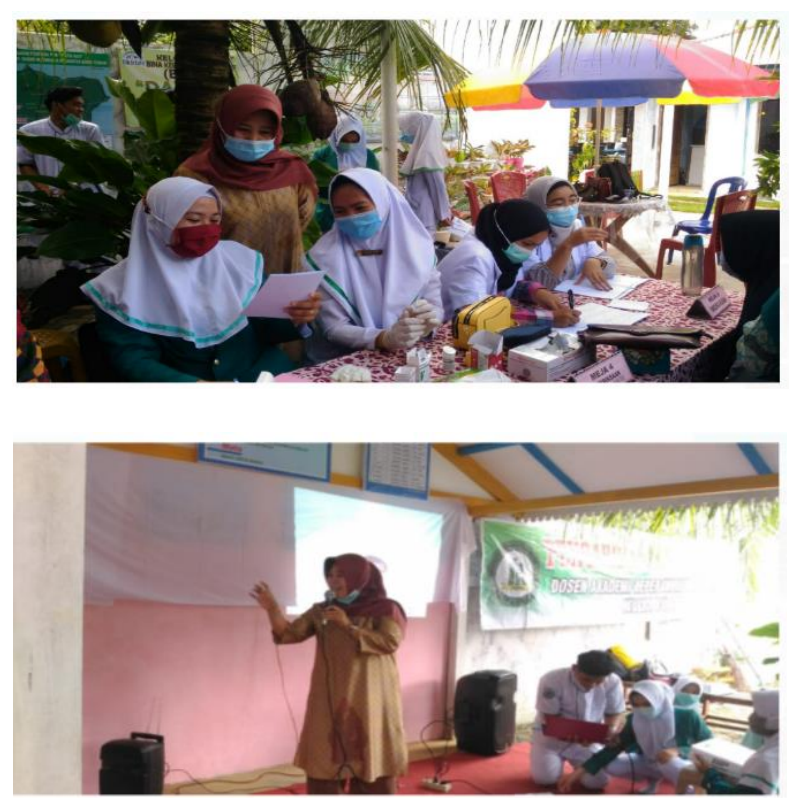

Gambar 2. Foto Kegiatan Pengabmas Edukasi

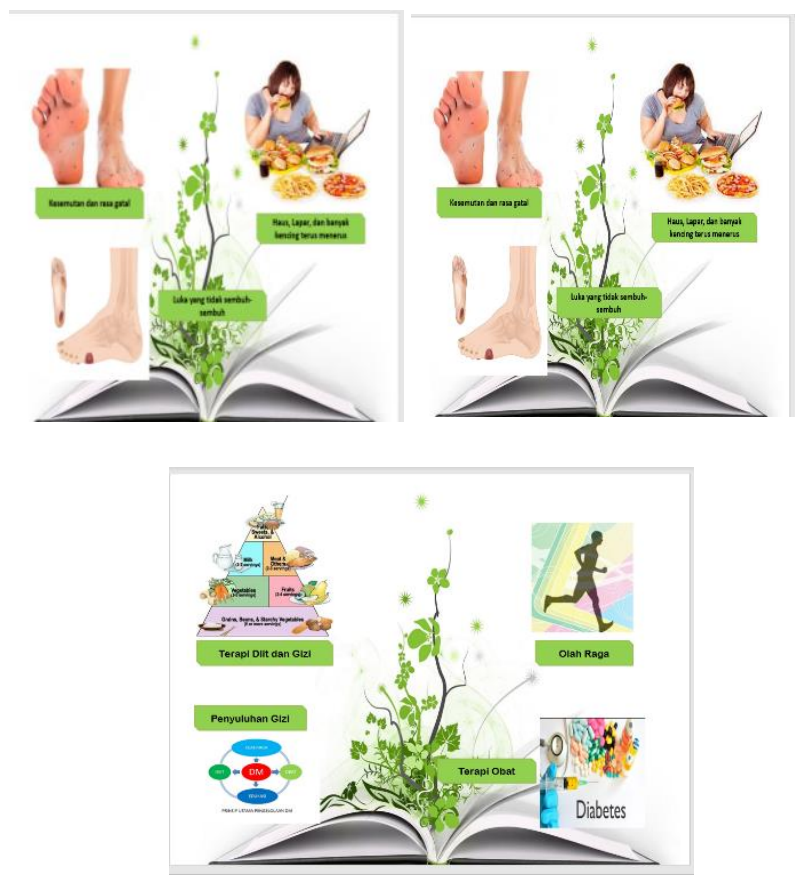

Gambar 3. Materi Penyuluhan Tentang Diabetes Melitus

\section{Simpulan Dan Saran}

Pengabdian masyarakat yang dilakukan dengan memberikan edukasi kesehatan dapat memberikan dampak bagi masyarakat dalam meningkatkan derajat kesehatan dengan salah 
Zahlimar, dkk. Edukasi Kesehatan Pencegahan Risiko Diabetes Melitus di Desa Sijau Kecamatan Rimbo Tengah Bungo

satu cara preventif resiko terjadinya komplikasi lebih lanjut Diabetes Melitus di masyarakat desa sijau Bungo.

Disarankan kepada masyarakat dan kader setempat selalu melakukan pemantauan pada masyarakat dengan kegiatan posbindunya.

\section{Daftar Rujukan}

Hidayah, M. (2019). Hubungan Perilaku SelfManagement Dengan Kadar Gula Darah Pada Pasien Diabetes Mellitus Tipe 2 Di Wilayah Kerja Puskesmas Pucang Sewu, Surabaya. Amerta Nutrition, 3(3), 176. https://doi.org/10.20473/amnt.v3i3.2019.17 6-182

IDF. (2017). Global Perspective on Diabetes. Diabetes Voice, 64(4), 1-32. www.idf.org

Kemenkes. (2017). Infodatin-Diabetes.Pdf.

Suriya, M. (2016). FAKTOR - FAKTOR YANG BERHUBUNGAN DENGAN KUALITAS HIDUP PASIEN. THE SHINE CAHAYA DUNIA S-1 KEPERAWATAN, 2(1), Kualitas hidup pasien Diabetes Mellitus sebagian $b$.

Woodall, J., White, J., \& South, J. (2013). Improving health and well-being through community health champions: A thematic evaluation of a programme in Yorkshire and Humber. Perspectives in Public Health,
$133(2)$,

96-103. https://doi.org/10.1177/1757913912453669

Zuriati, Z. (2018). Lentera Kesehatan 'Aisyiyah, 3(1): 244-249. 3(1), 244-249.

Hidayah, M. (2019). Hubungan Perilaku SelfManagement Dengan Kadar Gula Darah Pada Pasien Diabetes Mellitus Tipe 2 Di Wilayah Kerja Puskesmas Pucang Sewu, Surabaya. Amerta Nutrition, 3(3), 176. https://doi.org/10.20473/amnt.v3i3.2019.1 76-182

IDF. (2017). Global Perspective on Diabetes. Diabetes Voice, 64(4), 1-32. www.idf.org

Kemenkes. (2017). Infodatin-Diabetes.Pdf.

Suriya, M. (2016). FAKTOR - FAKTOR YANG BERHUBUNGAN DENGAN KUALITAS HIDUP PASIEN. THE SHINE CAHAYA DUNIA S-1 KEPERAWATAN, 2(1), Kualitas hidup pasien Diabetes Mellitus sebagian $b$.

Woodall, J., White, J., \& South, J. (2013). Improving health and well-being through community health champions: A thematic evaluation of a programme in Yorkshire and Humber. Perspectives in Public Health, 133(2), 96-103. https://doi.org/10.1177/175791391245366 9

Zuriati, Z. (2018). Lentera Kesehatan 'Aisyiyah, 3(1): 244-249. 3(1), 244-249. 